\title{
Home, Ethnicity and Sexuality in Shyam Selvadurai's The Hungry Ghosts
}

\author{
Rajorshi Das \\ Assistant Professor (ad-hoc), Indraprastha College for Women. \\ Email: dasrajorshi@gmail.com
}

Received May 10, 2017; Revised July 23, 2017; Accepted July 25, 2017; Published August 18, 2017.

\begin{abstract}
This paper explores the ways in which Shyam Selvadurai's The Hungry Ghosts (2013) conforms to the national underpinnings of the Sri Lankan and by extension South Asian diaspora while simultaneously choosing mourning over rage as a way of living together. In his overt reliance on a mythical structure and Buddhist philosophy, the author betrays the entry of the homonational body as an ideal citizen within the complex geopolitical aspirations of South Asia where family and ethnicity are integral to the formation of self. Race and region therefore reign supreme over questions of desire and companionate bonding.
\end{abstract}

Keywords: Shyam Selvadurai, The Hungry Ghosts, Queer Diaspora, Sinhalese, Tamil, Sexuality, South Asia, Buddhism

According to Yi-Fu Tuan (1977), a "hometown is an intimate place... its ugliness does not matter" (144 - 145). The Queer Home however deconstructs the idea of the "familial home" as the place of comfort and belonging (Fortier 2002: 2), challenging the heteronormative world-view of the nation-state. Home, therefore constitutes not where we are born but where we "assemble" (Sinfield 2000: 103). However, Shyam Selvadurai's The Hungry Ghosts (2013) conforms to the national underpinnings of the South Asian diaspora with a constant reliance on an allegorical structure that retrieves cultural myths to provide a historical validation to his narrative. In the process, he not only ignores the potentialities of the queer diaspora to redeem the narrow jingoistic aspirations of the Sinhalese identity but also suggests the emergence of the homonationalist as a viable category in South Asia where the law ironically (with the exception of Nepal) does not consider the homosexual within the purview of the discourse of rights and citizenship.

Set against the background of the contemporary Sinhalese-Tamil conflict in Sri Lanka, the novel dwells on the subject of Nostos (homecoming) as a means to negotiate the protagonist's ethnicity and gender performance. Born to a Tamil father and Sinhalese mother, the protagonist, Shivan is made keenly aware of his mixed ethnicity when during a riot, his grandmother, Aacho reminds her trusted guard, Chandralal that they "are registered as a Sinhalese house" (Selvadurai 2013: 63). The 1977 conflict between these two nationalities gives Shivan a perfect excuse to explore the West as the ultimate refuge for a sexual subaltern - "The idea of sexual freedom began to take root in me, too. If America offered such opportunity for sex with women, did it not offer similar opportunity for people like me?" (17). Shivan's decision to migrate is largely guided by his desire to sexually liberate himself thereby conforming to the Western narratives of acceptance

(c) AesthetixMS 2016. This Open Access article is published under a Creative Commons Attribution Non-Commercial 4.0 International License (http://creativecommons.org/licenses/by-nc/4.o/), which permits non-commercial re-use, distribution, and reproduction in any medium, provided the original work is properly cited. For citation use the DOI. For commercial re-use, please contact editor@rupkatha.com. 
and progression, rather than being an urgent need to escape any ethnic clashes whatsoever. According to Jasbir Puar (2013), homonationalism is a "facet of modernity and a historical shift marked by the entrance of (some) homosexual bodies as worthy of protection by nation-states, a constitutive and fundamental reorientation of the relationship between the state, capitalism, and sexuality" (337). Though Shivan finds refuge in Toronto, Canada, as a brown sexual minority, he is treated merely as an exotic Other. In her article in The Guardian Puar is critical of the celebration of selected queer lives by the It Gets Better project - "Although lauded by gay liberals for having 'done something' to address the recent spate of queer youth suicides; critics note that queer people of colour, trans, gender queer and gender nonconforming youth, and lesbians have not been inspirationally hailed by IGB (It Gets Better) in the same way as white gay male" (1). By not being a "prime steak" in the "meat market" of Toronto's gay subculture and hence not ready for consumption, Shivan attracted only the old and the ugly - "my foreignness was my appeal" (106) and has to soon join a coming-out group to overcome his isolation in the host country.

In Impossible Desires (2005) Gayatri Gopinath treats the 'Queer' as a category that can trouble the "nationalist ideologies" of the Indian diaspora "fully aligned with the interests of transnational capitalism" (11). She adds that "suturing 'queer' to 'diaspora' thus recuperates those desires, practices and subjectivities that are rendered impossible and unimaginable within conventional diasporic and nationalist imaginaries" (11). In Selvadurai, such a resistance is stunted by his conflation of desire with mere lust for power. While Shivan's sexuality situates him in direct confrontation with his grandmother's authority, it paradoxically allows him to recognize parallels in their respective quest for bodies that they can control. As a product of Sinhalese militant nationalism, Shivan's grandmother ${ }^{i}$ does not acknowledge her daughter who had married a Tamil but takes a personal liking to her Puthey (Shivan), completely ignoring her granddaughter in the process. It is this strangulating love that leads to the most traumatic experience of Shivan's life - "Everything she touched, everything she loved, disintegrated in her hands" (77). As a believer in the Buddhist philosophy of Karma, Selvadurai relies on the myth of "peretheya", the hungry ghost to highlight this singular and universal flaw of human desire exhibited by Aacho"They were born as peretheyas for their past crimes, reborn as slaves and faceless, as if a wall of flesh had grown over their features, just little holes for breathing, nothing else" (365). The hungry ghost is said to have "an enormous belly" and a "mouth no larger than that of an eye of a needle" thereby being unable to satiate its hunger, ever (24). While Shivan argues that his grandmother "saw herself as that naked perethi, marooned on an island, surrounded by so much that is good in life but unable to enjoy it" (77), the same metaphor applies to the protagonist who, as a privileged gay brown male diasporic subject, struggles to reconcile his homosexuality to his ethnic identity.

Gopinath (2005) states - "a queer diaspora...recognizes the past as a site of intense violence as well as pleasure, it acknowledges the spaces of impossibility within the nation and their translation within the diaspora into new logics of affiliation" ("Nostalgia, Desire, Diaspora" 275). In Selvadurai, this violence is enacted at both public and personal levels, emerging out of the civil war as well as the Sri Lankan legal system that criminalizes homosexuality. These two strands converge during Shivan's relationship with Mili Jayasinghe and the latter's humanitarian commitments to Kantha, a women's organization run by a professor, Sriyani Karunaratne. According to Avtar Brah (1996), "homing desire" is different from the desire for a homeland and implies the urge to be at home which may constitute a "mythic place of desire in the diasporic imagination" and by extension a "place of no return" (192). Shivan's return to Sri Lanka mythicizes his relationship with the nation which is not quite the "place of no return" as Brah implies but rather represents an umbilical attachment where he must return and confront his failings. This initially begins as a quest for self to retrieve his masculinity inhibited by white supremacy in the 
West. The protagonist shares a difficult relationship with all the three major women in his life, who constitute his biological family. Though his sister, Renu accepts his sexuality on the grounds that he too is a victim of the patriarchal order, Shivan's mother rejects it as a diseased condition "would have strangled you at birth" (129). His fraught relationship with his mother can be traced back to his childhood when he describes her as "Mother Fairest" for siding with his sister (42) even as he is pampered constantly by his grandmother. While Shivan insists that his decision to go back to Sri Lanka is guided by his concern for Aacho, it seems that this return is set to be a quest for an ideal lover rooted in his ethnic aspirations. He later remarks, "With Mili it felt so peaceful, this shared history, this elliptical way of talking, because we both understand the same world and its idioms" (169). Like Ruth Vanita and Saleem Kidwai in Same Sex Love in India (200o), Selvadurai resorts to the religio-mythical archive to legitimize the endemic nature of homosexuality in Sri Lanka. The myth of the Naga king Manikantha and the Hermit serves as a forewarning to the protagonist whose inability to understand the ground reality and consequent visibility/vulnerability of his relationship with Mili, prove fatal to the latter.

Like the two competing nationalisms, Shivan's ethnicity and sexuality seem to be in a state of perpetual conflict as he tries desperately to forge a stable "I". Selvadurai enhances Shivan's innate flaws by juxtaposing them with Mili's single-minded critique of masculinity. Though a centre of idolatry in his school, Mili risks giving it up by his charitable endeavours arising out of his rage against a philandering father. It is this Queer anger that he manages to channelize exposing the violent machinations of the Sinhalese state. Shivan on the other hand regains his masculinity by swift application of his grandmother's resources. During an encounter with a tenant, he is called a "ponnaya" (182) - a term of insult used to emasculate the receiver. Incidentally the same term was earlier used by his mother to berate his father "railing at his weakness and incompetence" (19). It is ironical that Chandralal whose help he now seeks to be "truly a man" (184) should later be the cause of his biggest tragedy. While Shivan notices the Sinhalese graffiti with inscriptions like "Tamil pariah", "Tamil dogs" and "Rape a Tamil woman for Lanka", it is not until Ranjini's death that he realizes that the police atrocities are not an aberration but a universal methodology to erase all forms of opposition to the state. Being a key member of Kantha, Ranjini had already been jailed by the special Task Force once and was seen as a pivotal voice against the human rights abuses committed by the Sinhalese government. While Shivan tries to convince Mili to give up his work and migrate to Canada, the latter provides a vehement critique of his performance of masculinity that is rooted in his identification with the Sinhalese nation-state - "Don't think I have not noticed how you've changed since taking up your grandmother's work, strutting around like a mahattaya" (109). Though Sriyani warns Shivan to be discreet, he and Mili recklessly visit a "bloody whorehouse" meant for foreigners (221) only to be followed by goons of Chandralal and later confronted by his grandmother. Though Shivan insists that it is "my nature", Aacho as a self-made guardian of Sinhalese culture, alludes to Mili's mother's "vile European blood" as a corrupting influence (222, 223). The nation survives through a reiteration and circulation of enemies against whom the ideal citizen needs to be constantly measured. Having already been identified by the state apparatus as dangerous or even antinational, Mili now becomes the sexual pervert, a cultural contaminant ironically charged with polluting the mind and body of Shivan, who is now a Canadian citizen. Mili's queer dissent against the state which is an extension of his family makes him a "disposable minority" (Bristow 1997: 20). Visibility entails vulnerability and this is further complicated by Shivan's outburst - "No Aacho, I don't love you.... I have never loved you" (Selvadurai 223). In an interview with NOW Toronto magazine, Selvadurai remarks - "In Buddhism, anger is considered the primary destroyer, but it's actually fear that's at the root of all negative feelings. The more angry somebody is, the 
more frightened they are" (Susan Cole). While Aacho has systematically used her trusted goons to execute her tasks in the past, it is her fear of losing Shivan forever that makes her order Chandralal to kidnap Mili from Sriyani's beach house, their usual site of love-making. It is also Mili's murder and not Shivan's migration that finally attests the latter's status as a stranger in his erstwhile familiar/familial homeland - "you misjudged this country, because you are now foreign to it" (241). Eager to fix responsibility Shivan now associates his personal tragedy with the history of the nation - "Remember how you said our Sinhalese ended up eating themselves by causing the riots? Now you have eaten yourself. Through your stupidity and evil, you have lost the thing you valued the most" (243).

Selvadurai's reliance on Buddhist tales also results in a mythification of India's role in the conflict - "So I knew that as in those Buddhist tales, the karmic crime of hatred between the Sinhalese and the Tamils had taken on a new incarnation.... India, under pressure from its massive Tamil population has intervened" (138). There is a further critique of India's aggressive stance when in a seminar in Toronto, Sriyani concludes that "neither the Tamils nor the Sinhalese wanted this (Indian) force that acted increasingly like an occupying army" (277). She also distances herself from Western feminist ideology by responding to a question on the merits of giving sewing machines, a symbol of domesticity and femininity, to Sri Lankan women - "Who are we Western feminists, to tell these women what they should or should not?" (278). Like Sriyani's argument, Aubrey Collette's 1956 cartoon, 'Help! Help! I don't want to be saved' (Figure 1) is nondiscriminatory towards any political ideologies, relying on the reader's literacy to get his message across.

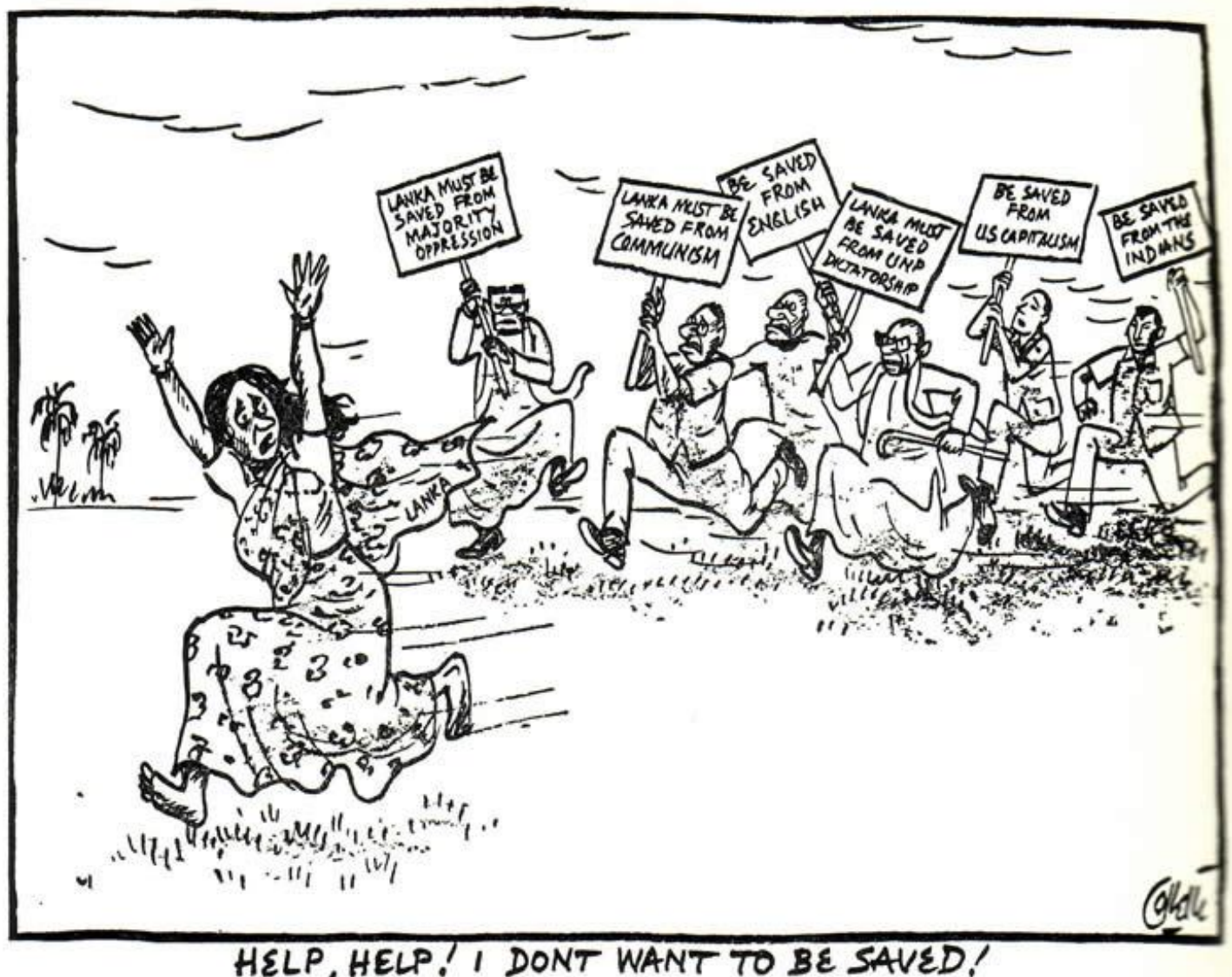

Figure 1. 
With respect to Indian calendar art Sumanti Ramaswamy writes - "the geo-body is feminised in a highly specific way, as a Hindu/Indian woman whose body is generally demurely clad in a saree and wearing all markers of traditional identity" (180). Such an image, Ramaswamy argues is meant to indicate that the Bharat Mata is under the protection or guardianship of her loyal sons. Collette's cartoon can be interpreted as a counter to this heteronormative formulation of the nation as a woman in distress. His Lanka is an aged woman who runs away from his apparent saviours, pleading to be left alone. It can be read as a reversal of the game of dicing episode in The Mahabharata where Draupadi seeks help from all the men in the royal court to save her from the ongoing humiliation. Collette's cartoon therefore is a rejection of hegemonic masculinity that is celebrated as the saviour of the nation. This is also unlike the cartoons of R K Laxman where India and Sri Lanka are represented in territorial landscapes with strong pro-Tamil and pro-Indian messages.

Shivan's initial rejection of his grandmother can be seen as a Queer diasporic subject's rebuttal of his childhood home and family built on the tenets of masculinity and heteronormativity - "a bana maduwa cannot erase a murder" (245). Mili therefore must die to make space for Michael - an almost forced authorial intervention required to complete Shivan's identification with the hungry ghost. Unlike Shivan, Michael hails from a stable home with the complete support of his parents. Haunted by Mili's memories and pricked by his mother's visit, the protagonist finally reveals his traumatic past to Michael who now feels betrayed.

"Do you love me, Michael?

$M e$ ? What me would I love? I don't know you at all. I have been living with a stranger" (340)

The novel emphasizes the need to forgive and forget as way of living together, as explicated by the myth of 'The Demoness Kali' and her transformation to Bhadra Kali (the merciful). In On Cosmopolitanism and Forgiveness (2005), Jacques Derrida distinguishes between two kinds of forgiveness, one that is "unconditional" "granted to the guilty as guilty" including those who do not repent and the other which is conditional and proportional to repentance and transformation in the guilty (34). Since Aacho refuses to take responsibility of her crime, Shivan has to forgive the unforgivable (a Derridean Impossibility) which is the only way to bury the ghosts of the past -

"Michael is wrong when he says my greatest challenge will be to win my grandmother's forgiveness. She will take me back because I am to her like rain on parched land. The true question is how I will deal with her refusal to admit culpability in Mili's death, her impenetrable self-righteousness...I feel my failure, my anger" (363).

As a political exile, Selvadurai's Toronto offers him a "safe place" from where he can write "unsafe novels" (Toronto Book Awards interview). Yet his prototype, Shivan must give up his relationship with Michael to retrieve his lost homeland, thereby suggesting the obfuscating (at least temporarily) of his Queer sexuality to perform the role of a good grandson and by association that of a good citizen. In privileging Aacho over Michael, Shivan reiterates a Yayati-like parable ${ }^{\mathrm{iii}}$ that the old always encompasses the young through memory and nostalgia in the subcontinent. Shivan re-enacts the concept of karma is his final decision -

"It is I who must give up Michael, not he who will leave me; I who must break us out of our cycle of anger, then peace then anger again. This time I will save the person I cherish most by giving him up. My past has tainted Michael.... He has become something he does not recognize" (370) 
Shivan's decision to mourn his loss is an act of queer agency that rejects the comfort and care of his host nation and seeks to address the loneliness of his grandmother. In choosing to dwell on his hurt and vulnerability, he refuses to give in to rage as a means of closure. It is only by taking care of his grandmother who represents his community and family that Shivan can take care of his "self" and arrive at self-knowledge ${ }^{\text {iv }}$. However, one cannot ignore the political ramifications of a text that attempts to redeem the image of Buddhism in the aftermath of the recent extremism of BBS (Bodu Bala Sena) - a hardline Buddhist group that proclaims itself to be the self-appointed guardians of the Sinhalese identity. The author's silence over the emerging hostilities against Muslims in Sri Lanka leaves much room to reinvestigate the mode and timing of his novel.

Brett Bowden writes - "it is this extremist adherence to nationalist pride that has been implicated in precipitating upon humanity some of its darkest moments and more horrendous of crimes" (240). While The Hungry Ghosts is an attempt to capture Selvadurai's own diasporic consciousness as an expatriate in Canada, his celebration of Buddhist myths as a way of reconciliation fails to adequately reject the violence that is intrinsic to nationalism. It rather betrays a somewhat jingoistic attempt privileging state politics over cosmopolitanism, majoritarianism over minority consciousness. His insistence on religious (and not necessarily only spiritual) moorings to move ahead with the peace process in Sri Lanka, erases of all minority concerns - be it ethnic or sexual - in the novel. However, in privileging mourning over rage, the author manages to provide an alternate and a more complicated understanding of the Sri Lankan queer diaspora.

\section{Notes}

${ }^{\mathrm{i}}$ The figure of the grandmother as an embodiment of the lofty ideals of Nationalism is a recurrent literary device in post-independent South Asian literature. Thamma in Amitav Ghose's The Shadow Lines (1988) is another such example.

ii The unfinished bana maduwa as institutionalized religion is symbolic of the grandmother's desperate attempt to cleanse her guilty conscience.

iii According to the myth of Yayati, the puranic king was cursed with premature old age and could only get his youth back if one of his sons agreed to swap their ages. Since Yayati's youngest son Puru is the only one who consents to the arrangement, the king chooses him as the heir apparent.

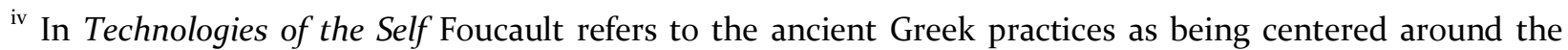
philosophy of the "care of the self" which is a pre-condition to operationalize the Delphic principle, gnothi sauton ("know yourself").

\section{References}

Bowden, Brett. (2003). Nationalism and Cosmopolitanism: Irreconcilable Differences or Possible Bedfellows? National Identities 5.1, 234-249. Retrieved 2 March. 2016 fromhttp://www.tandfonline.com/doi/abs/10.108o/1460894031000163139?journalCode=cnid20

Brah, Avtar. (1996). Cartographies of Diaspora: Contesting Identities. London: Routledge.

Bristow, Joseph. (1997). Sexuality. London: Routledge

Collette, Aubrey. (cartoonist). Help! Help! I don't want to be saved! [Ink on paper],Retrieved 9 May, 2017 
Derrida, Jacques. (2005) On Cosmopolitanism and Forgiveness. (Simon Critchley andRichard Kearney, Trans). London \& New York: Routledge.

Gopinath, Gayatri. (2007). Impossible Desires: Queer Diasporas and South Asian Public Cultures. Calcutta: Seagull Books.

Gopinath, Gayatri. (2005). Nostalgia, Desire, Diaspora: South Asian Sexualities in Motion. InTheorizing Diaspora: A Reader. Jana E Brazial and Anita Mannur (eds). Oxford: Blackwell Publishing.

Fortier, Anne-Marie. (2002). Queer Diaspora. In Handbook of Lesbian and Gay Studies. Diane Richardson and Steven Seidman (eds). Thousand Oaks, CA: SAGE.

Ramaswamy, Sumathi. (2003). Visualising India’s Geo-body: Globes, Maps, Bodyscapes in Beyond Appearances? Visual Practices and Ideologies in Modern IndiaNew Delhi: SAGE.

Puar, Jasbir. (2010). In the Wake of It Gets Better. Retrieved from 28 November 2 https://www.theguardian.com/commentisfree/cifamerica/2010/nov/16/wake-it-gets-better-campaign (guardian.org)

Puar, Jasbir.(2013) Rethinking Homonationalism. IJMES 45, 336-339. Retrieved 5 Jan, 2016from https://www.researchgate.net/publication/259432632_Rethinking_Homonationalism

Selvadurai, Shyam. (2013, April 11). Interview. Susan G Cole. NOW Toronto Magazine. Retrieved 3 March, 2015 from https://nowtoronto.com/art-and-books/shyam-selvadurais-the-hungry-ghosts/

Selvadurai, Shyam. (2014, Sept 19). Interview. Toronto Book Awards. Retrieved 5 March, 2015 from https://www.youtube.com/watch?v=7SkdFd 4 NQSI

Selvadurai, Shyam. (2013). The Hungry Ghosts. Penguin Viking: New Delhi.

Sinfield, Alan. (2000) Diaspora and hybridity. Queer identity and the Ethnicity Mode. In Diaspora and Visual Culture. Representing African and Jews. N Mirzoeff (ed). London: Routledge.

Tuan, Yi-Fu. (1977). Intimate Experiences of Place. In Space and Place; the Perspectives of Experience. Minneapolis: U of Minnesota Press.

Rajorshi Das is currently teaching at Indraprastha College for Women. He is particularly invested in Queer Studies. 